\title{
Classification of Music Instruments: An overview
}

\section{Parsuram Prasad Poudel}

Lecturer (Music-Tabla), Lalitkala Campus, T.U.

Email: parsuram.poudel@gmail.com

DOI: https://doi.org/ 10.3126/irjmmc.v2i4.41548

Received: September 23, 2021; Revised \& Accepted: September 30, 2021; Published: December 22, 2021

(C) Copyright: Poudel (2021).

\begin{abstract}
Varieties of music instruments are available today to produce the audible sounds which are used to make a piece of music. The music instruments have been classified into various groups depending upon the size, materials, usages, structure, and others. But, today many new practices, experiments, devices, and new instruments have been emerged with the flow of time in musical field. For all the concerned with music, a neo-classification of instruments is ever raised a question. So, from the educational point of view, some of the new music instruments, which are played today, further should be re-classified for convenience. The present article is based on an overview upon the study about the music instruments by following the secondary data and analytical method. After interpretation and analysis, some music instruments, which are still unclassified are categorized under neo-classification.
\end{abstract}

Keywords: Classification, music instruments, naad, Natyashastra, organology.

\section{INTRODUCTION}

Music is a form of art to express the human feelings and emotions. Generally, the audible sounds are the mandatory input for each piece of music. No music is possible without creation of sounds. It is one of the nutritious food of the human brain ( Poudel, 2021). In general, the sound, one is melodious and another is a harsh sound. Simply, the melodious sound is applicable in music creation. In the eastern philosophy, the sound is referred to Naad, which means 'word', according to Samskrit-Nepali dictionary (Gautam, 2068). The word 'Aum' is considered as an ultimate sound through which the creation began, according to the eastern religions; Hinduism, Buddhism, and Sikhism. In the western society, the study of music instrument in known as organology (Magnusson, 2017) and in eastern society, this subject is studied in musicology. According to a search in google "vibrations that travel through the air or another medium and can be heard when they reach a person's or animal's ear" (Sueur, 2018), that is sound. Many music theoretician have stated their own views in reference with the musical sound and the classification of music instruments, time by time. There are two types of sounds in this world according to Sangitmakarananda; Aahat and Anaahat Naad (Telang, 1920, p.1). The Aahat Naad is the sound applicable in music and Anaahat Naad could not be listened by others except an expert person. So, Aahat Naad is the audible by everyone and arranging various those sounds, a music piece is presented. According to Danielou (1968, p. 21), "Intelligent sound (Naad) is the treasure of happiness of 
a happy winner of the heart of hearer, the first messenger of God of love"(Danielou, 1968). In this sense, the above mentioned intelligent sound is the source of salvation. Sound is the result after many processes. These sounds are generated with the help of some substances. If two or more surfaces strike or rub or contact with each other, the sound is produced (Basanta, 1991, p. 58). Sound is a pressure wave that consists of tiny fluctuations in the air pressure. The air is the medium through which the produced sound is transferred to hearing organ. Three elements are necessary for the production of a sensation of sound (Zakar \& Dahiru, 2018 , p.48). The first substance for the production of musical sound is the vibrating substance through which the sound generates. The second one is the channel or medium that is air and the last one is the sense organ that is the ear. Another necessary factor for creating the audible sound is the striker or the causing factor. In absence of these four factors, no sound can be produced. In a text, the author found silence about the medium and sense organ (Mishra, 1992, p.11).

For music, the music instruments are the source of the sound. When a stroke or power or vibration is placed at the vibrating parts of the instrument, the generated sound travels through the air and hits with eardrum and lastly, the sensation of sound is felt by the receiver. The following shows the process of sound production in music.

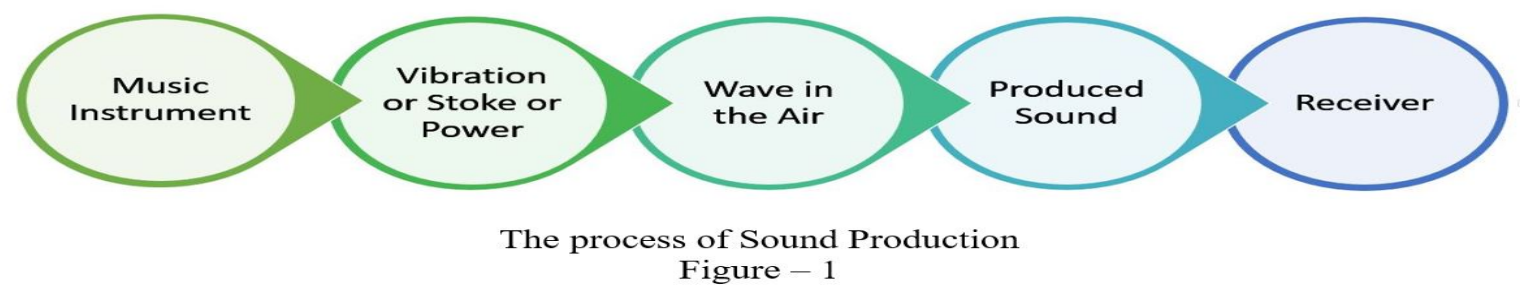

\section{MATERIALS AND METHOD USED}

The present research article is based on literature reviews. Library visit and web surfing were the major activities to gather the information to solve the research problems. Figure and table are the major tool to present the data. Secondary data were interpreted and analyzed to draw the result.

\section{CLASSIFICATION OF MUSIC INSTRUMENTS}

Many musicians have stated and texts have been published describing the types of music instruments. Eastern society and western society, both have categorized their music instruments more commonly. Based on various factors, i.e. range, size, role, usage, geography, body, and the composition of the material used in instruments, we can find many classifications of music instruments, to date. Many ancient texts of music are there, where the chapters of classification of music instruments can be found. Sangitmakaranda states that the sound can be verified into five types namely, Nakhaj, Vayuj, Charmaj, Lohaj and Shariraj as ... नखयावायुजचर्माणि लोहशारिरजास्तथा ... (Telang, 1920, p. 2). Here, the author has described Nakhaj instruments as those instruments which are played with finger or bow or other types of hammering substances on the string part of the instrument. Vayuj instruments produce sound by blowing. Charmaj types of instruments, which are made of skin and are played with hand parts or sticks. According to Narada, Lohaj instruments are made of metal or sometimes clay. These instruments produce the sound with the vibration from the whole body of the 
same instruments when the stroke is made. The last one, Shariraj is the vocal cord of living beings. Basically, the instruments can be classified into melodic instruments and percussion instruments according to the notes produced. Melodic instruments are used for playing the music piece by applying 7 notes of music (Do, Re, Mi, Fa, So, La, and Shi), and their varieties. In eastern epics, Shadaj, Rishav, Gandhar, Madhyam, Pancham, Dhiawat and Nishad are seven major music notes (Acharya, 2068) which are applicable in the instruments Swar-Baja (Melodic instruments), which are alternately known as note-based instruments (Poudel, 2021, p.41). Likewise, the percussion instruments (Taal-Baja) are those which are essential for metering or showing the rhythm to ease the melody. In other sentences "Such rhythmic instruments are, in other meaning, is known as percussion instrument which measure the speed of music or movement and current of music composition (Poudel, 2021, p.41). In another text "एकं ईश्वरनिर्मितं नैसर्गिकम अन्यचतुर्बिधं मनुष्यनिर्मितं चेति पण्चप्रकारा: महाबाद्यानाम" is clearly stated in Sangeet Chudamani as cited by Mishra (1992). Meaning that, among the five types of instruments, four are man-made and one specific is made by God. Likewise, sage Bharat in between second century BC and second century AD has classified the music instruments into four groups as "ततं चैवानद्दं च घनं सुषिरमेव च, चतुर्विधं च विजेमातोद्यं लक्षणान्वितम", in his text Natyashastra (Malaviya, 1997, p.107, 401). 'Sangeet Ratnakar' is another eminent digest of music composed during the 13th century by pandit Sharangadev. He has also classified the instruments as Tat, Sushir, Avanadda, and Ghana in the lines as "...ततं सुषिरं चावनद्दं घनमिति स्मृतम चतुर्धा..." (Chaudhari, 2006, p. 249). Further, he has described that Shruti (Music Notes) are played in Tat and Sushir instruments; Avanadda instruments are played for entertaining people and Ghana instrument is for the measurement of time in music.

Benjamin has described five types of musical instruments available in eastern countries as Tat, Bitat, Sushir, Dhol, and Ghana (Benjamin, 1968) in the context of Indian music. In his book, the stringed instruments are categorized as Tat and Bitat. Tat instruments are those played with stroke or plucking and Bitat instruments are those played with the bow by rubbing. Likewise, fourth type of instruments, as he stated with strange name as Dhola, a roaring instrument, includes Damaru, Pakhawaj, and Madal. A text composed by Mr. Dahyalala Sivarama, also has some explanations about the instruments. According to him, Tat, Bitat or Anaddha, Sushir and Ghana are four types "ततं बिणादिकं वाद्यमानद्दं मुरजादिकम / वंशादिकं तु सुषिरं कांस्यतालादिकं घनम //" as stated (Sivarama, 2006, p. 122). The question arises here that why the author did use Bitat or Aanadda name for Awanaddha instruments which are quite remarkable difference with the opinion by Benjamin (1968). Another tome has expressed as "ततं वीणादि सुषिरं वंशादि मुरजादि च / अवनद्दं घनं कांस्यं तालादि परिकिर्तितम //६३//" (Kumbhakarna, 1963, p. 26). In consonance with this text, the classes of instruments are of four as same above expressed. In the Tamil literature, the instruments are divided into five sections namely, Torakrubi (Skin Instruments), Tulaibakrubi (Holed instruments), Narampukkarubi (Instruments made with animal tissue), Mittakrukkarubi (Human Voice) and Kanchakkarubi (Hammering Percussion Instruments) (Pagaldas, 1995). Similarly, Chinese society has categorized the music instruments into eight classes known as $B \bar{a} y \overline{i n}$. Chu 
instruments are string instruments which are plucked or bowed or struck, $M u$ instruments, which are played through blowing into holes or reed, Hiyan instruments are played by making stroke with hand or sticks, Che instruments are played with striking to the a number of tablets of stones hung. Likewise, Kin instruments, Tu instruments, Po instruments, Ko instruments are others (Horner \& Ayers, 1998) (Hurworth, 2011). Musician Ramashanker (1995) has further classified the instruments (Vadya) into 3 groups in accordance with the accompaniment point of view: Geetanug (instruments for accompanying with vocal), Nrityanug (instruments for accompanying with dance) and Shushka Vadya (instruments for solo performance). According to the another text "Sangeet Ratnakar", namely, Geetanug, Nrityanug, Shushka Vadya and Dwayanug (the instruments played with vocal and dance) are the four classes of instruments, as stated "शुष्कं गीतानुगं नृत्तानुगमन्यद्वूयानुगम चतुर्धेति मतं वाद्यं..." (Chaudhari, 2006, p. 252). "Sangeet Chudamani" is another eminent text about classical music, composed by Kavichakravarti Jagadekmalla. In this, the author has written in reference with music instruments in Sanskrit sentences as, "ततं च बिततं चैब घनं सुषिरमेव च / गानं चैब तु पंचैतत पंचशब्दा: प्रकिर्तिता: // (Jagadekmalla, 1958). The presented statement indicates that Avanadda Vadya and Bitat are taken as synonym words. Likewise, Vocal music is also counted as an instrument. So, there are five sources of musical sounds.

In the context of music in Japan, there are only three classifications as percussion, stringed and wind instruments ("Japanese Musical Instruments," 2021). An article has described four classes of instruments in European countries, namely: idiophone, membranophone, chordophone, and aerophone (Lee, 2019). At present, many of the musical texts, research articles and theoreticians have followed the four classifications of instruments as Tat, Avanadda, Ghana, and Sushir. If we surf the internet searching the classification of music instruments, sites answer in many ways. Some are found with the instruments of three classes, i.e. percussion, wind and string instruments ("Musical Instruments," 2019). In 1940, Sachs introduced the electrophone category as a response to new musical materialities, such as oscillators, filters, pickups, and amplifiers (Magnusson, 2017, p. 287). Another site (Westrup, 2020) suggests five families of instruments as percussion, stringed, keyboard, wind, and electronic. In this context, electronic and electric instruments are said to be new classification. This class of instruments neither made with strings nor any component to vibrate nor to blow. The electric energy automatically produces the various sounds as per the necessity. At present, many electric and electronic music instruments have emerged in music field. Even, many classic instruments have turned into electric/tronic form. Companies have been manufacturing both types of same instruments since decades, i.e. Sitar and e-sitar, guitar and e-guitar, harmonium and keyboards, drums and e-drums, tabala and e-tabala. More than that, such electric/tronic instruments carry the features of multifunctionality, such as; sound bank, recording, polyphonic performance, programming. More ideas have been proposed in a book (Kallen, 1955) as the groups of instruments as: percussion, woodwind, brass, strings, keyboard, and digital instruments. The classic piano supposed to come under string family in the one hand, according to Kallen (1955), he has equalized the keyboard with piano on the other hand. 
The music instruments are classified with their shape too. In an article by Uddav, he referenced from Kumari (2014) that the instruments can be classified into eight major groups depending upon the shape of the instrument. The following figure (2), is presented to clarify the groups (Uddav, 2021 ).

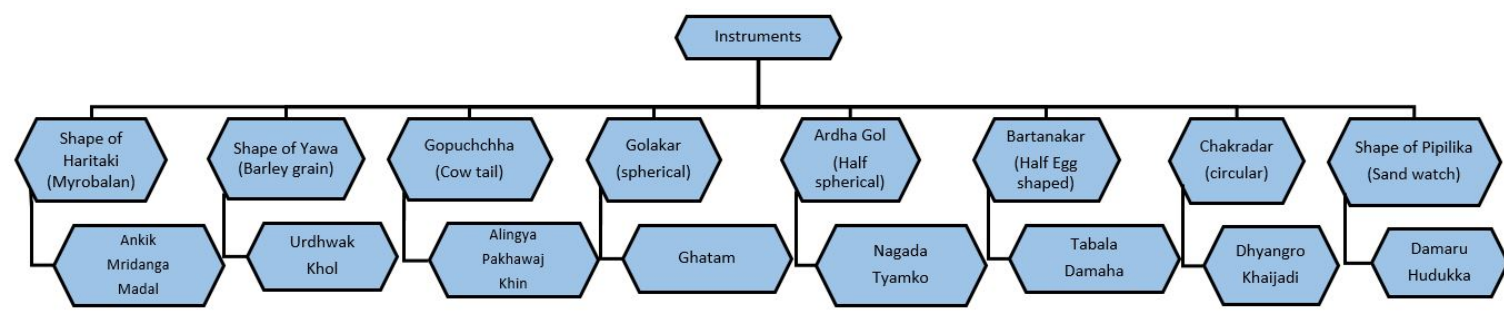

Classification of percussion instruments according to shape

Figure 2

Another study has divided the instruments into two families: monophonic and polyphonic instruments (Chandwadkar, 2013, p. 9). The monophonic instruments produce one sound of note at a time. The proper examples of monophonic instruments are the flutes, classical violin, Tabala, Ghatam, Sitar, Tanpura, Veena, Shehanai, conch, bell, and others. Polyphonic instruments are those instruments which produce more sounds at a time i.e. Harmonium, piano, guitar, Santoor, and others. Greek music has three classes of music instruments (Ancientgreecefacts.Com, 2021) as string instruments, drum instruments and wind instruments. Musician and social activist Kandel has described seven classes of music instruments, four melodious and three rhythmic instruments, in his book (Kandel, 2003, p. 3). According him, plucking instruments, bowing instruments, wind instrument with finger, wind instrument without finger, hammered instruments, skinned instruments with Khari (black tuning paste or Syahi), and skinned instruments without Khari are the major classes of instruments.

There is another way to classify the instruments depending upon the purpose and feature of music piece. The instruments played for performing classical and semi classical music are generally classified as classical instruments. For example, veena, sitar, tabala, pakhawaj, flute, sarod, sarangi, and others. Likely, the instruments used in tribal community or the instruments used in folk music can be considered as folk and tribal music instrument, i.e. flute, sarangi, murchunga, madal, jhyali, tyamko, khanjari, nagara (Yatri, 2041, p.268), and others. Modern music instruments are those which is internationally common, like guitar, drum, keyboard, kongo, electric/tronic instruments and others. Similarly, the ritual instruments are played during the spiritual, ritual and religious actions, occasionally. Dhime, khin, conch, bell, kaha, dhyangro, nagada, are some examples of ritual instruments (Tingey, 1992). So, these instruments can be categorized as tribal instruments too. There are many other instruments which have been played during religious ceremony only. Some instruments are played during a particular event only, like mourning, funeral, birthday, marriage, and others (Regmi, 2015). The role of the instruments can be another basis to classify, again. The main instrument is that which is followed or accompanied by others and vice versa. Although the world is globalized today, western and eastern instruments are also here on the basis of geography. 


\section{RESULT AND DISCUSSION}

Natyashastra was composed by sage Bharata during the second century BC to second century AD (Sen, 1994, p. 32). In this era, It can be assumed that only few instruments were in practice. So, the classification of instruments became easier and limited up to four classes as Tat, Awanaddha, Sushir and Ghana. According to him, Tat instruments are stringed instruments that produce the sound after plucking or striking or rubbing the strings, inserted in instruments. Avanadda instruments are those as Charmaj as explained by sage Narada, which are made with skin, that vibrates after the stroke. Likewise, Ghana and Lohaj can be defined as the same, which produce the sound from whole body of itself after stroke or vibration and Sushir instruments and Vayuj instruments are synonyms with each other. The names of instruments during the Natyashastra were Veena, Ektara (chordophones), Tri-Pushkar, Dardur, Pataha or Dholak, Mridang, Dunduvi or Damaha, Mardal or Madal (Skinned Percussion or membranophones), Jhallari or cymbal or Jhyali, Kaans or metal-plate, Panav or Kathatala (Idiophone), Vamshi, Shankha, Tundakini (aerophone) (Bhattarai, 2039, p. 600). Later, all of the theoreticians and musicians adopted the same theory of sage Bharata till today, except in Sangitmakaranda, and Sangeet Chudamani Sangeet where, another family of instrument is considered as Shariraj, the vocal cord of living being. In Sangeet Chudamani, the 'Bitat' word is used in place of 'Avanadda'. Thus, this researcher found another word Aanadda (Sivarama, 2006, p. 122). So, sometimes it creates confusion among Bitat, Avanadda and Aanadda. In this researcher's assumption, these three words are synonym words. Likewise, there are five classes of instruments as per the Indian scholar Kohl as stated “पंचधा च चतुर्धा च त्रिविधं च मते मते। कोहलस्य मते ख्यातं पंचधा वाद्यमेव च।।", which is expressed by Prof. Lal Mani Mishra (1992, p.13) referring Sangeet Chudamani, in his study work. Sage Narada has classified the instruments into three groups as stated "नारदमते चार्मणं तान्तिकं घनं चेति त्रिधा वाद्यलक्षणम्।" (Jagadekmalla, 1958, p. 69). It indicates that during the era of Narada only skin instruments, string instruments, and hammering (Ghana) instruments were popular. But the question arises here: Why had Narada missed the name of such a popular and inevitable instrument, the flute (Sushir)? Referring to another eminent ancestor of eastern music Taansena, Mishra (1992) has stated that even Taansena has used the word 'Bitat' in place of Awanaddha. So, it's clear that both of these are same. During the 21 st century, many kinds of instruments were developed as per the convenient, time by time. Today, several instruments have been manufactured and carrying the features of both, stringed and skinned instruments. Sarangi, Sarod, and Tungna are made with skin, but these are not percussion instruments. Similarly, another instrument 'Bhapang' is made with string, but this instrument is for rhythmic purpose not for melodious purpose. The Tibetan instrument, singing bowl needs hammering and vibrating, both action. Another famous instrument piano looks like harmonium, but produces sound from strings after strokes, as the Kashmiri instrument Santoor produces. Similarly, other instrument made of several solid plates, arranged in chromatic order, have been also in practice in musical field i.e. xylophone, Jal-Taranga, Kastha-Tarang. Though, these instruments represent Ghana Vadya family in eastern geography, and in the Idiophone family in western. But, Tabala-Taranga, and MadalTaranga are used for melodies purpose rather than rhythmic purpose. Kastha-Taranga, and 
Loh-Taranga are Ghana Vadya, but used as melodic instruments. Depending upon the number of musical notes produced at a time, this article mentions another types of instrument that is homophonic instruments which produce the two sounds at a time with same rhythm, same note but in next pitch as same instruments i.e. harmonium. With the invention and development of power from electricity, some of the musical instruments have been turned into electric and electronic form, i.e. electric guitar, synthesizer, keyboard, e-violin, e-drum, octopad in the western society and e-sitar, zitar, e-Tanpura, e-tabala, nagma or lehara machine in the India. Electric music instruments or Vidhyut-Baja need the sound inputs through stroke or bowing or hammering by acoustic means, as in natural instruments which can be controlled or amplified or modified using electricity power (David, 2016). But electronic music instruments generate the musical sounds through electronic components such as microchips, microelectronic circuits, transistors, diodes, capacitors, resistors, and others. Companies have been manufacturing both types of same instruments, acoustic as well as electric/tronic since decades, i.e. Sitar and e-sitar, guitar and e-guitar, harmonium and keyboards, drums and edrums, tabala and e-tabala, tanpura and e-tanpura. This class of instruments (electric/tronic) is neither made with strings nor involved any components to vibrate or to blow. The electric energy automatically produces the various sounds as per the necessity. More than that, such electric/tronic instruments carry the features of multifunction, such as; sound bank, recording, polyphonic performance, programming, arranging. In this context, electronic and electric instruments can be next classification. This researcher has pinpointed major classes of instruments, depending on diverse views, in the table given below:

\begin{tabular}{|l|l|l|}
\hline \multicolumn{1}{|c|}{ Basis } & \multicolumn{1}{|c|}{ Classification } & \multicolumn{1}{|c|}{ Particular } \\
\hline Vibrating materials & $\begin{array}{l}\text { Tat (String or } \\
\text { Chordophone) }\end{array}$ & $\begin{array}{l}\text { String part of instrument vibrate after stroke, } \\
\text { bowing, hammering. }\end{array}$ \\
\cline { 2 - 3 } & $\begin{array}{l}\text { Avanadda or } \\
\text { Anaddha or Bitat }\end{array}$ & $\begin{array}{l}\text { Skin or membrane vibrates after stroke. Made } \\
\text { for rhythmic purpose. }\end{array}$ \\
\cline { 2 - 3 } & $\begin{array}{l}\text { Sushir (Wind or } \\
\text { Aerophone) }\end{array}$ & Sound is produced after blowing. \\
\cline { 2 - 3 } $\begin{array}{l}\text { Shape of percussion } \\
\text { instrument }\end{array}$ & $\begin{array}{l}\text { Ghana ( Solid or } \\
\text { Idiophone ) }\end{array}$ & $\begin{array}{l}\text { The whole body produces the sound after } \\
\text { stroke. Both melodic and rhythmic use. }\end{array}$ \\
\cline { 2 - 3 } & Spherical & Duff, Chang, Tambourine, Dhyangro. \\
\cline { 2 - 3 } & Half spherical & Nagada, Tyamko. \\
\cline { 2 - 3 } & Half egg shaped & Tabala, Damaha. \\
\cline { 2 - 3 } & Sand watch shape & Damaru, Hudukaa. \\
\hline Role & $\begin{array}{l}\text { Main Instrument } \\
\text { (Anga Vadya })\end{array}$ & $\begin{array}{l}\text { Veena, Sitar, Sarod, Flute, Shehanai, Sarangi, } \\
\text { Tabala, and others. }\end{array}$ \\
\cline { 2 - 3 } & Secondary & Tanpura, \\
\hline
\end{tabular}


International Research Journal of MMC (IRJMMC)

Vol. 2

Issue 4 (December, 2021)

\begin{tabular}{|c|c|c|}
\hline & $\begin{array}{l}\text { instruments } \\
\text { (Pratynga Vadya) }\end{array}$ & $\begin{array}{l}\text { Kathatala, Jhyali, Chimta, Dholak, Dhaa, and } \\
\text { others. }\end{array}$ \\
\hline \multirow[t]{2}{*}{$\begin{array}{l}\text { Geography/ } \\
\text { Community }\end{array}$} & $\begin{array}{l}\text { Western } \\
\text { instruments }\end{array}$ & $\begin{array}{l}\text { Drum, Guitar, Xylophone, Violin, Harmonium, } \\
\text { Mouth organ, Saxophone, Clarinet, and others. }\end{array}$ \\
\hline & $\begin{array}{l}\text { Eastern } \\
\text { instruments }\end{array}$ & $\begin{array}{l}\text { Veena, Pakhawaj, Sitar, Tabla, Ishraj, Sarod, } \\
\text { Sarangi, Dilruba, Flute, Shehanai, } \\
\text { Harmonium, and others. }\end{array}$ \\
\hline \multirow[t]{3}{*}{ Usage /Application } & $\begin{array}{l}\text { Classical \& Semi } \\
\text { classical } \\
\text { instruments }\end{array}$ & $\begin{array}{l}\text { Veena, Pakhawaj, Sitar, Tabla, Ishraj, Sarod, } \\
\text { Sarangi, Dilruba, Flute, Shehanai, } \\
\text { Harmonium, and others, which are played to } \\
\text { perform classical based compositions. }\end{array}$ \\
\hline & $\begin{array}{l}\text { Folk and Tribal } \\
\text { instruments }\end{array}$ & $\begin{array}{l}\text { Dhol, Dholak, Duf, Sarangi. Murli, Flute, } \\
\text { Shehanai, Tyamko, Panche- Baja, Nau-Baja, } \\
\text { Binayo and many others. These are associated } \\
\text { with particular caste and musical heritage. }\end{array}$ \\
\hline & $\begin{array}{l}\text { Modern } \\
\text { instruments }\end{array}$ & $\begin{array}{l}\text { Guitar, Drum, Violin, clarinet, Harps, } \\
\text { Keyboards and others. }\end{array}$ \\
\hline \multirow[t]{2}{*}{ Sound (Note) } & $\begin{array}{l}\text { Melodic } \\
\text { Instruments }\end{array}$ & $\begin{array}{l}\text { All the instruments which are played for } \\
\text { presenting musical notes to make melody. }\end{array}$ \\
\hline & $\begin{array}{l}\text { Rhythmic } \\
\text { Instruments }\end{array}$ & $\begin{array}{l}\text { All the instruments for performing rhythmic } \\
\text { patterns. }\end{array}$ \\
\hline \multirow[t]{2}{*}{ Power } & Acoustic & $\begin{array}{l}\text { Veena, Sitar, Guitar, Tabla, Madal and other } \\
\text { manual instruments which produce sound after } \\
\text { hammering, bowing, plucking, and blowing. }\end{array}$ \\
\hline & Electric/Electronic & $\begin{array}{l}\text { All the instruments like guitar, sitar , drum } \\
\text { which produce sound after a connection to } \\
\text { electric/tronic power, as well as the sound can } \\
\text { be modified as necessity. }\end{array}$ \\
\hline \multirow[t]{2}{*}{ Source of sound } & $\begin{array}{l}\text { Natural } \\
\text { instrument }\end{array}$ & $\begin{array}{l}\text { Human vocal cord (Shariraj) as stated in some } \\
\text { ancient texts. }\end{array}$ \\
\hline & $\begin{array}{l}\text { Artificial } \\
\text { instrument }\end{array}$ & All the man-made instruments. \\
\hline \multirow[t]{2}{*}{$\begin{array}{l}\text { Occasional/Ceremonial } \\
\text { Instruments }\end{array}$} & $\begin{array}{l}\text { Ritual and } \\
\text { religious } \\
\text { instruments }\end{array}$ & $\begin{array}{l}\text { Damaru, Dhyangro, Conch, Bell, Kaha, } \\
\text { Ghanta, Damaha, Bone made instruments, } \\
\text { which are played in special occasion and time } \\
\text { only, with special purpose. }\end{array}$ \\
\hline & $\begin{array}{l}\text { General } \\
\text { instruments }\end{array}$ & $\begin{array}{l}\text { All the instruments which can be played at any } \\
\text { time, especially for entertainment. }\end{array}$ \\
\hline
\end{tabular}




\section{CONCLUSION}

Music is the garland of musical notes which are produced from the instruments after blowing or hammering or bowing or rubbing the certain parts of instrument. As this article discussed above about organology, all those instruments can be classified in five major families: Tat (stringed instruments), Avanadda (Membranophones), Sushir (Wind Instruments), Ghana (Idiophone instruments or solid) and Vidhyut-Baja (Electronic Instruments). This study emphasizes the new category of music instruments as Electronic instruments which do not need any membrane or string or cord or wind as traditional instruments, rather produce sound through the microchips. This researcher feels the necessity for carrying out further study concerning the types and uses of the musical instruments, especially for educational purpose. However, only few traditional texts of eastern musicology and few regions were taken under the review to discuss the research title, the finding can be beneficial for those who are associated with organology.

\section{REFERENCES}

Acharya, S. (2068). Ashraya Ragamrit -2. In Sangitamrit Publication (Vol. 1). Kathmandu, Nepal.

ancientgreecefacts.com. (2021). Retrieved October 13, 2021, from http://ancientgreecefacts.com/greek-musical-instruments/

Basanta. (1991). Sangit Visharad. In Sangit Karyalaya Hathras (Vol. 19).

Benjamin, W. (1968). Hindu World. In George Allen \& Unwin Ltd. (Vol. 2). Retrieved from https://archive.org/details/hindu-world-vol.-2-an-encyclopedic-survey-of-wisdombenjamin-walker/page/96/mode/2up?q=kohala+music

Bhattarai, G. (2039). Bharat ko Natya Shastra. In Nepal Academy.

Chandwadkar, D. M. (2013). Identification of musical instruments and swara raga in Hindustani classical music using signal processing techniques (Savitribai Phule Pune University). Savitribai Phule Pune University. Retrieved from http://hdl.handle.net/10603/126268

Chaudhari, S. (2006). Sangit Ratnakar (Expaination ). In Radha Publication (Vol. 3).

Danielou, A. (1968). Ragas Of Northern Indian Music. In Barrie \& Rockliff (Barrie Books Ltd.). Retrieved from https://archive.org/details/ragasofnorthernindianmusicalaindanielou/page/n4/mode/1up?q $=$ Sangit + Chudamani

David. (2016). Electric and electronic instruments. Retrieved October 12, 2021, from https://www.daviddarling.info/encyclopedia_of_music/E/electric_and_electronic_instru ments.html

Gautam, K. (2068). Bhagawatananta. In Janaki Jivan Kunj.

Horner, A. B., \& Ayers, L. (1998). Modeling Chinese musical instruments. The Journal of the Acoustical Society of America, 103(5), 3043-3043. https://doi.org/10.1121/1.422612

Hurworth, G. (2011). Chinese musical instruments: An introduction. Taylor and Francis Online, 16(1), 77-79. https://doi.org/10.1080/08145857.1993.10415234

Jagadekmalla, K. (1958). Sangeet Chudamani. In D. Velankar (Ed.), Sangeet Natak Academy, Delhi. New Delhi.

Japanese Musical Instruments. (2021). Retrieved October 1, 2021, from https://www.japan- 
zone.com/culture/instruments.html

Kallen, S. A. (1955). The instruments of music. In The Music Library, London. Lucent Books. Retrieved from https://archive.org/details/instrumentsofmus0000kall/mode/2up

Kandel, R. P. (2003). Folk musical instruments of Nepal. In Museum of Nepalese folk instruments (1st ed.). Kathmandu, Nepal: Museum of Nepalese folk instruments.

Kumbhakarna. (1963). Sangeet Raaj. In P. Sharma (Ed.), Hindurajya Vishwavidhyalaya Nepal Rajya Samskrit Granthamala (Vol. 5).

Lee, D. (2019). Hornbostel-Sachs Classification of musical instruments. City Research Online, 47(1), 72-91. Retrieved from https://openaccess.city.ac.uk/id/eprint/22554/

Magnusson, T. (2017). Musical organics: a heterarchical approach to digital organology. Journal of New Music Research, 46(3), 286-303. https://doi.org/10.1080/09298215.2017.1353636

Malaviya, S. (1997). Natyashastram. In Krishna Das Academy (Vol. 106). Krishnadas Academy, Varanasi.

Mishra, L. (1992). Bharatiya Sangit Vadya. In Kanishka Publication. Delhi.

Musical instruments. (2019). Retrieved October 8, 2021, from CK-12 Foundation website: https://flexbooks.ck12.org/cbook/ck-12-middle-school-physical-science-flexbook2.0/section/17.8/primary/lesson/musical-instruments-ms-ps/

Pagaldas, D. R. (1995). Tabala Kaumudi -3. In Ramchandra Sangitalaya, Gwaliwar.

Poudel, P. (2021). Ubiquity of music and its prevalence - some approaches. Sangeet Galaxy Indian Music Journal, 10(2), 49. Retrieved from https://sangeetgalaxy.co.in/

Poudel, P. P. (2021). Mass perception about music during lockdown in Nepal. International Journal of Asian Education, 2(4), 472-479. https://doi.org/10.46966/ijae.v2i4.230

Regmi, D. C. (2015). View of Nepalese music instruments and mourning rituals: from permission to proscription. The Journal of University Grants Commission, 4(1), 6. Retrieved from http://www.jugc.edu.np/index.php/JUGC/article/view/68/72

Sen, D. A. K. (1994). Indian concept of rhythm. In Kanishna Publication. Delhi.

Sivarama, D. (2006). Sangeet Kaladhar. In P. Sharma (Ed.), Sangeet Natak Academy. New Delhi: Sangeet Natak Academy, New Delhi.

Sueur, J. (2018). Sound analysis and synthesis with R. https://doi.org/https://doi.org/10.1007/978-3-319-77647-7

Telang, R. (1920). Sangit Makaranda. In Central LIbrary, Baroda.

Tingey, C. (1992). Musical instrument or ritual object? the status of the kettledrum in the temples of central Nepal. British Journal of Ethnomusicology, 1, 7. Retrieved from https://www.jstor.org/stable/3060729

Uddav, P. (2021). Origin, development, classification and historicity of ancient percussion instruments. Journal of Fine Arts, 3(1), 31-36.

Westrup, J. A. (2020). Musical instrument history, characteristics, examples, \& facts. Retrieved October 8, 2021, from Britannica website: https://www.britannica.com/art/musical-instrument

Yatri, P. (2041). Bheri Lok Sahitya. In Nepal Academy.

Zakar, M., \& Dahiru, D. (2018). A riview of the principles and applications of sound wave. Journal of Applied Physics, 9(6), 48-61. https://doi.org/10.9790/4861-0906044861 